\title{
Hepatosplenic Gamma/Delta T-Cell Lymphoma Masquerading as Alcoholic Hepatitis and Methadone Withdrawal
}

\author{
H.A. Lopez Morra S.N. Fine G. Dickstein \\ Department of Medicine, MetroWest Medical Center, Framingham Union Hospital, \\ Framingham, Mass., USA
}

\section{Key Words}

Hepatosplenic gamma/delta T-cell lymphoma - CD20 positivity · Alcoholic hepatitis . Methadone withdrawal

\begin{abstract}
Hepatosplenic gamma/delta T-cell lymphoma is a rare neoplasm of mature gamma/delta T-cells with sinusoidal infiltration of spleen, liver, and bone marrow. Patients are predominantly adolescent and young adult males and usually present with marked hepatosplenomegaly. Pancytopenia is another common finding. Despite an initial response to treatment, patients have a median survival of one to two years. In this report, we document a case of alcoholic hepatitis and methadone withdrawal masquerading unsuspected, hepatosplenic gamma/delta T-cell lymphoma with unusual CD20 positivity.
\end{abstract}

\section{Case}

A 32-year-old woman presented to MetroWest Medical Center with constipation, urinary retention, crampy lower abdominal pain, and jaundice. Her medical history was remarkable for polysubstance abuse (alcohol and opiates) and prior terminated pregnancy. Medications included an over the counter laxative and methadone $130 \mathrm{mg}$ PO daily. For two months prior to admission, she had consumed six cans of beer a day and frequently complained of fatigue and diaphoresis which resulted in a gradual increase in her methadone dose in treatment of presumed opiate withdrawal. Physical examination on admission revealed jaundice, abdominal distension, hepatomegaly and right upper quadrant tenderness. Her body mass index was 26. Pertinent laboratories revealed WBC 10,000/ $\mathrm{mm}^{3}$, HGB $13.8 \mathrm{~g} / \mathrm{dl}, \mathrm{HCT}$ $40 \%$, PLT 123,000/ $\mathrm{mm}^{3}$, total protein $6.5 \mathrm{mg} / \mathrm{dl}$, albumin $3.0 \mathrm{mg} / \mathrm{dl}$, total bilirubin $6.5 \mathrm{mg} / \mathrm{dl}$ (4.3 direct), AST 645 IU/l, ALT 256 IU/l, alkaline phosphatase 256 IU/l, INR 1.42 and ammonia $88 \mu \mathrm{mol} / \mathrm{l}$ (normal 11-51 $\mu \mathrm{mol} / \mathrm{l})$. Virologic and serologic markers for hepatitis A, B, C, EBV, HSV, HIV and HTLV I/II were negative. Abdominal ultrasound revealed hepatosplenomegaly without ductal dilatation. There was no ascites. A clinical diagnosis of alcoholic hepatitis was made and she was started on prednisolone $40 \mathrm{mg}$ PO daily. She developed encephalopathy that responded to lactulose. Over nine days, 


\begin{tabular}{|c|c|c|c|}
\hline $\begin{array}{c}\text { CaseReportsin } \\
\text { Gastroenterology }\end{array}$ & $\begin{array}{l}\text { Case Rep Gastroenterol 2007;1:84-89 } \\
\text { D0I: } 10.1159 / 000107654\end{array}$ & Published online: September 20, 2007 & \begin{tabular}{|l} 
@ 2007 S. Karger AG, Basel \\
ISSN 1662-0631 \\
www.karger.com/crg
\end{tabular} \\
\hline
\end{tabular}

aminotransferases improved to AST of $47 \mathrm{IU} / \mathrm{l}$ and ALT of $122 \mathrm{IU} / \mathrm{l}$. However, bilirubin and alkaline phosphatase continued to rise, peaking at $32.5 \mathrm{mg} / \mathrm{dl}$ and $390 \mathrm{IU} / \mathrm{l}$, respectively. A liver biopsy was performed which revealed a diffuse infiltrate of small to intermediate sized lymphoid cells, degenerated hepatocytes and marked cholestasis (fig. 1). Immunoperoxidase studies of the lymphoid cells showed $+\mathrm{CD} 3$, -CD79a, -CD5, -CD10, -TdT, and surprisingly +CD20 (fig. 2). An attempt was made to stain for CD56 and DNA extraction for PCR analysis; however, insufficient tissue remained in the section for evaluation. A diagnosis of hepatosplenic T cell lymphoma with unusual staining of CD20 (and +CD3) was favored. Bone marrow aspirate and immunoperoxidase stains (fig. 3 ) demonstrated involvement by lymphoma with a similar immunophenotypic profile as seen in liver. Our patient underwent six cycles of cyclophosphamide/fludarabine, and rituximab given the CD20 positivity. She experienced a complete response to this treatment as documented by PET scan and bone marrow biopsy four months later, only to recur fatally seven months following diagnosis.

\section{Discussion}

Hepatosplenic gamma/delta T-cell lymphoma is a rare neoplasm of mature gamma/delta T-cells with sinusoidal infiltration of spleen, liver, and bone marrow. Patients are predominantly adolescent or young adult males and usually present with marked hepatosplenomegaly [1]. Patients typically present with B symptoms (fever, weight loss and night sweats), hepatosplenomegaly, and pancytopenia. Occasionally, thrombocytopenia is the most striking finding $[2,3]$. Despite a relatively bland histopathologic appearance, this is an aggressive tumor with a median survival of only one to two years; relapse and death are common despite an initial response to chemotherapy [1-4]. In this patient, initial complaints of sweats and fatigue were misinterpreted as methadone withdrawal. When she continued to deteriorate despite increasing doses of methadone, she presented with urinary retention and constipation as side effects of opiate use. Moreover, heavy, regular alcohol intake, AST > ALT, jaundice, organomegaly, hypoprothrombinemia, and encephalopathy were interpreted and treated as alcoholic hepatitis. When labs worsened despite treatment, liver biopsy was done and favored hepatosplenic T-cell lymphoma. Of interest, CD20 positivity, to the best of our knowledge, has not been documented in the literature for this type of lymphoma and accounted for the addition of rituximab to the patient's regimen.

We are taught 'When you hear hoof beats behind you, don't expect to see a zebra' which came from the original phrase 'Don't look for zebras on Greene Street' (the location of the University of Maryland Hospital in Baltimore) [5]. Sometimes, even our time tested aphorisms prove false. CD20 positive hepatosplenic gamma/delta T cell lymphoma masquerading as alcoholic hepatitis and opiate withdrawal - a zebra on any street. 


\begin{tabular}{c|l|l|l}
$\begin{array}{c}\text { CaseReportsin } \\
\text { Gastroenterology }\end{array}$ & $\begin{array}{l}\text { Case Rep Gastroenterol 2007;1:84-89 } \\
\text { D0I: 10.1159/000107654 }\end{array}$ & Published online: September 20, 2007 & $\begin{array}{l}\text { O 2007 S. Karger AG, Basel } \\
\text { ISSN 1662-0631 } \\
\text { www.karger.com/crg }\end{array}$ \\
\hline
\end{tabular}

Fig. 1. Histopathology specimen showing diffuse infiltration of liver sinusoids (low-power-view, left) by intermediate sized lymphoid cells with irregular convoluted nuclear contours and associated with degenerated hepatocytes (high-power-view, right).
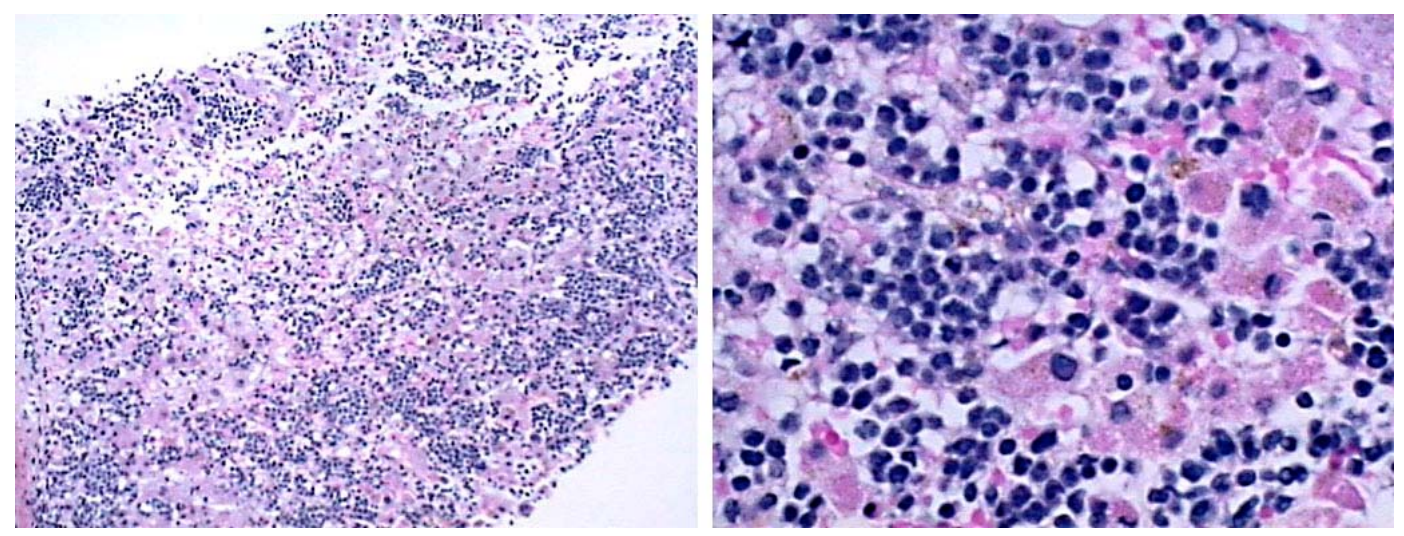


\begin{tabular}{c|l|l|l}
$\begin{array}{c}\text { CaseReportsin } \\
\text { Gastroenterology }\end{array}$ & $\begin{array}{l}\text { Case Rep Gastroenterol 2007;1:84-89 } \\
\text { D0I: 10.1159/000107654 }\end{array}$ & Published online: September 20, 2007 & $\begin{array}{l}\text { O 2007 S. Karger AG, Basel } \\
\text { ISSN 1662-0631 } \\
\text { www.karger.com/crg }\end{array}$ \\
\hline
\end{tabular}

Fig. 2. Immunostains from liver biopsy demonstrating CD3 positivity (left column) and CD20 positivity (right column). Above: low-power view; below: high-power view.
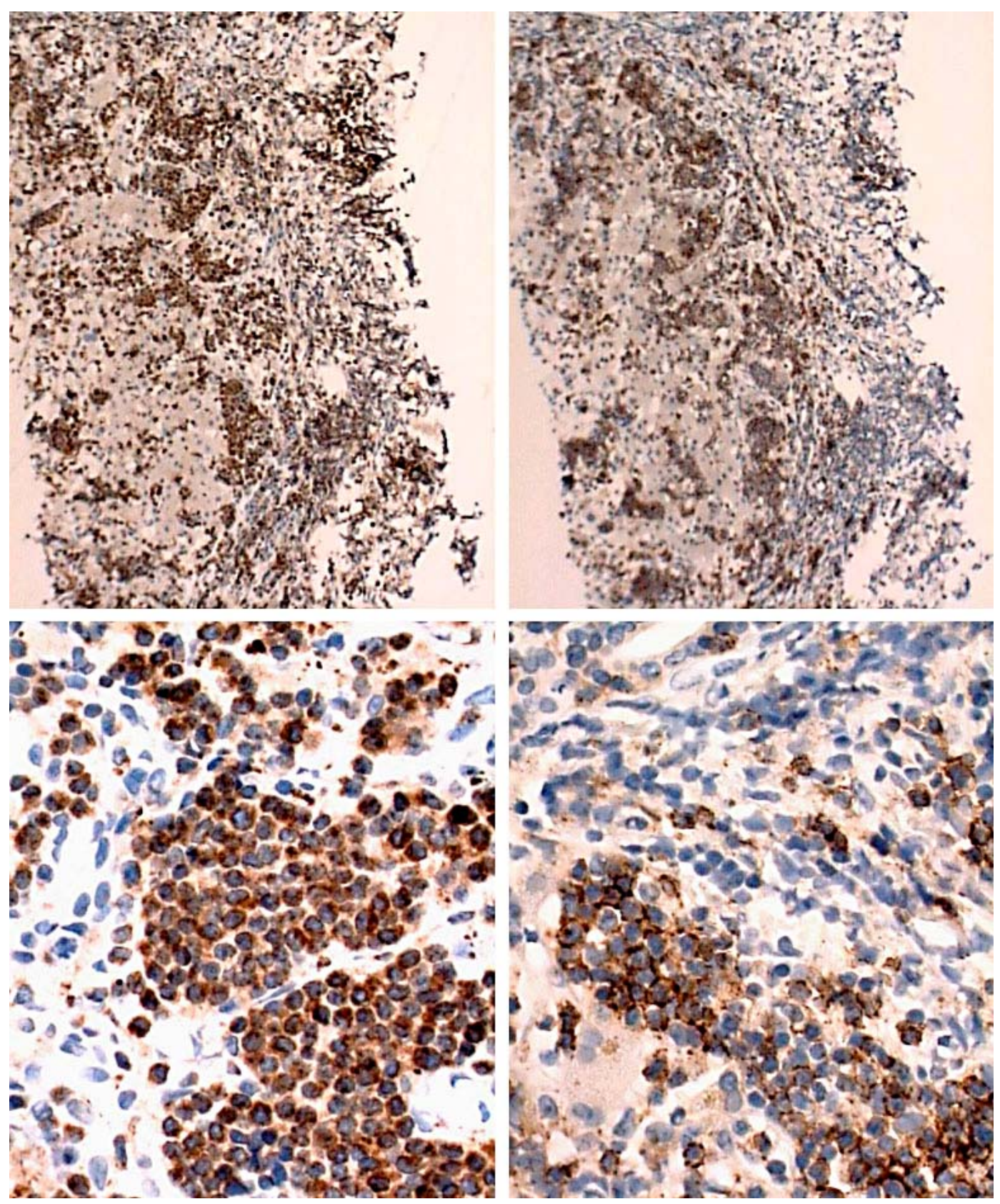


\begin{tabular}{c|l|l|l}
$\begin{array}{c}\text { CaseReportsin } \\
\text { Gastroenterology }\end{array}$ & $\begin{array}{l}\text { Case Rep Gastroenterol 2007;1:84-89 } \\
\text { D0I: 10.1159/000107654 }\end{array}$ & Published online: September 20, 2007 & $\begin{array}{l}\text { @ 2007 S. Karger AG, Basel } \\
\text { ISSN 1662-0631 } \\
\text { www.karger.com/crg }\end{array}$ \\
\hline
\end{tabular}

Fig. 3. Immunostains from bone marrow aspirate demonstrating CD3 positivity (left) and CD20 positivity (right).

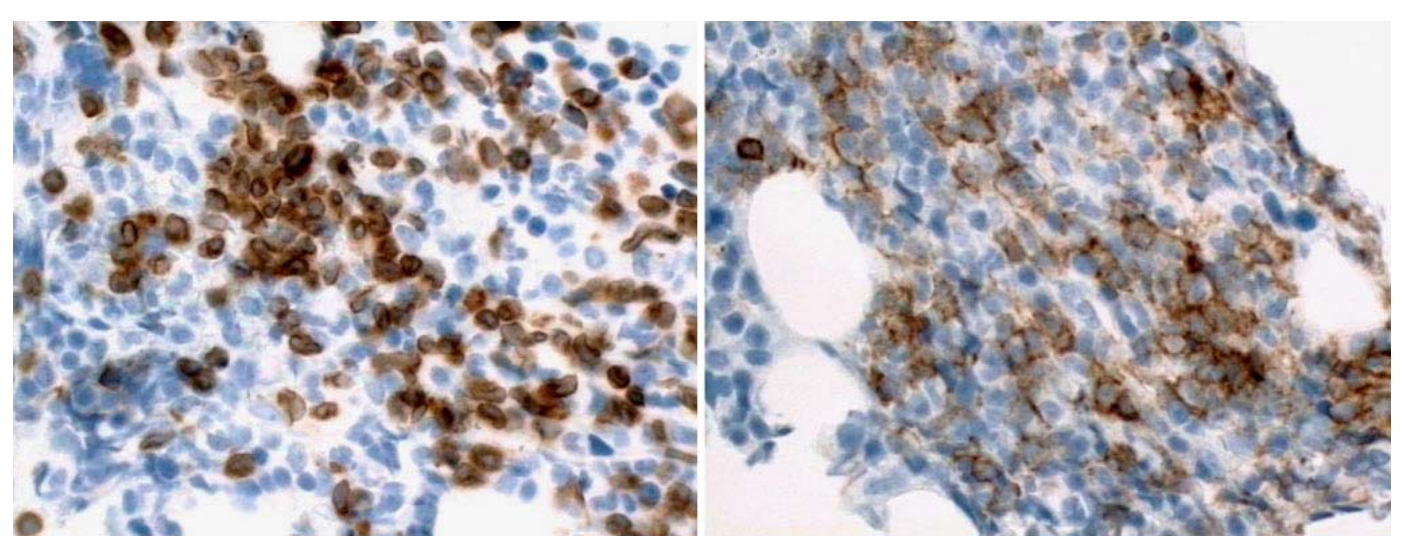




\section{References}

1 Farcet J, Gaulard P, Marolleau J, et al: Hepatosplenic T-cell lymphoma: Sinusal/sinusoidal localization of malignant cells expressing the T-cell receptor gamma delta. Blood 1990;75:2213-2219.

2 Cooke C, Greiner T, Raffeld M, et al: Gamma/delta T-cell lymphoma: A distinct clinicopathologic entity. Mod Pathol 1994;7:106A.

3 Cooke C, Krenacs L, Stetler-Stevenson M, et al: Hepatosplenic T-cell lymphoma: A distinct clinicopathologic entity of cytotoxic gamma delta T-cell origin. Blood 1996;88:4265-4274.

4 Belhadj K, Reyes F, Farcet JP, et al: Hepatosplenic gammadelta T-cell lymphoma is a rare clinicopathologic entity with poor outcome: Report on a series of 21 patients. Blood 2003;102:4261-4269.

5 Woodward TE: Circa 1950 according to www.zebracards.com. 